\title{
Green jobs in Argentina: opportunities to move forward with the environmental and social agenda
}

\author{
Christoph Ernst, Ana Sofía Rojo Brizuela \\ and Daniele Epifanio
}

\begin{abstract}
The Argentine economy has been becoming greener because of a new political orientation, international commitments (the Paris Agreement and the 2030 Agenda for Sustainable Development) and private sector initiatives. This transition is having economic and social impacts. The aim of the present article is to determine the potential of the economy to create green jobs that protect workers and the environment. In 2015, $7 \%$ of formal jobs were green and presented better average employment conditions than the rest. They were predominantly in goods production and the provision of urban services, such as sanitation and transport. Regulations and public policies seem to be the main factors driving green job creation, with consumption still playing a minor role. For the transition to a green economy to be fair, policies must take account of the employment dimension in order to initiate a virtuous circle leading to a more productive, inclusive and environmentally friendly economy.
\end{abstract}

\section{Keywords}

Employment, environment, climate change, environmental economics, employment creation, decent work, environmental protection, sustainable development, employment statistics, Argentina

\section{JEL classification}

J01, Q01, 001

\section{Authors}

Christoph Ernst is an employment and production development specialist at the International Labour Organization (ILO) Country Office for Argentina. Email: ernst@ilo.org.

Ana Sofía Rojo Brizuela is an economics graduate from the University of Buenos Aires, Argentina. Email: sofia.rojo.sr@gmail.com.

Daniele Epifanio is a political science graduate from the Guido Carli Free International University for Social Studies, Italy. Email: danepi91@gmail.com. 


\section{Introduction}

Climate change is one of the main challenges facing humanity in the coming decades. Its economic, social and environmental consequences threaten vast sections of the planet's population, particularly in the poorest regions. In response, countries have set an environmental policy agenda that may have both positive and negative effects on their societies and economies.

Argentina's geographical position and production structure mean that it is particularly affected. Natural disasters such as river and coastal flooding, droughts, extreme temperatures and fires are becoming more and more frequent. Agriculture, which is fundamental to the country's development and the global food supply, is the most vulnerable to these phenomena. Energy security is another sensitive issue, as it is being affected by the increasing intensity and duration of heat waves. Urban activities in general are being permanently impacted by the negative effects (MAyDS, 2017b).

In view of the need to adapt the most vulnerable systems and sectors to the international environmental agenda and a growing awareness of the need to respect the environment, policies for a greener economy are being implemented in Argentina. Different factors are driving this paradigm shift: political will at the different levels of government; the production sector, often prompted by the demands of external markets; and society in general, where responsible consumption practices are still incipient (Voices Research and Consultancy, 2016).

The transition to a green economy brings many opportunities and challenges. Incorporating technological change, stimulating innovation, investing in infrastructure and developing value chains associated with the emergence of new sectors are processes that provide the opportunity to create jobs with new employment profiles, while adapting the occupational skills of current profiles (Altenburg and Assmann, 2017; OECD, 2017). To capitalize on this potential, there is a need to formulate policies, create incentives and establish institutional frameworks that improve resource management and contribute to the transition. The nature of the challenges means that some sectors will inevitably have to be transformed. The transition to a green economy will be fair to the extent that it is inclusive. Creating decent work in the new activities and implementing social protection policies to mitigate the effects on the sectors that need transforming are the main channels for ensuring this inclusiveness.

By green jobs are meant those that meet the requirements of decent work and help preserve and restore the environment. They may be in traditional sectors, such as manufacturing or construction, or in new emerging sectors, such as renewable energy and energy efficiency (Jarvis, Varma and Ram, 2011). Green jobs are crucial for a fair transition.

The study on green employment in Argentina focuses on the jobs being created as a result of this transition and notes among its findings that the country had some 650,000 such jobs in 2015, employing $7 \%$ of formal wage earners (ILO, 2017). The study is part of the Green Jobs Programme initiative of the International Labour Organization (ILO), which has carried out similar research in different countries, notably Argentina, Brazil, Mexico and Uruguay in Latin America (ILO, 2009, 2013a, 2016 and 2017). The present article is based on the aforementioned study on green employment in Argentina and examines aspects such as the sectors in which green jobs are being created, the worker profiles benefiting and the quality of that employment, while showing the interdependence between the environmental, production and labour dimensions. It also seeks to demonstrate that in countries with production structures like Argentina's, a shift towards greater environmental sustainability is compatible with greater production development and the creation of decent work, particularly if environmental, production and labour policies are coordinated.

The article is structured as follows. First, it presents the main issues in the debate on a fair transition to a more sustainable economy, while highlighting the role of green jobs in the transition and 
defining the concept of green employment. Second, estimates of green employment in the country are presented by means of a sectoral analysis. Third, the link between environmental, production and labour policies is discussed. Lastly, the conclusions are presented.

\section{Sustainable development and the creation of decent jobs}

International concern about climate change goes back almost half a century. The 2030 Agenda for Sustainable Development, adopted by the United Nations General Assembly in September 2015, and the 17 Sustainable Development Goals (SDGs) associated with the Agenda have given a fresh impetus to global strategies to eradicate poverty, protect the planet and ensure prosperity for all.

In this new paradigm, public policies and institutions are organized around an environmental big push that is transforming the production and consumption structure and pursuing the incorporation of technical progress, sustainability and equality. This situation offers the opportunity to create high-quality jobs, increase productivity (which would make social policies more sustainable) and strengthen universal minimum income systems, unemployment insurance and mechanisms to protect workers and reintegrate them into the labour market. A fair transition for the workforce towards sustainable economies and societies can thus be sought (ILO, 2011 and 2016; ECLAC, 2016).

\section{The effects of climate change and environmental policy on employment: the need for a fair transition}

Climate change has many effects on the labour market. The high frequency of extreme weather events affects urban employment, with damage to transport systems, infrastructure and settlements impairing workers' ability to switch or find employment, for example. Agriculture, tourism, insurance, forestry, fisheries, infrastructure and energy are some of the sectors most vulnerable to the direct effects of climate change, as they depend on the weather (ILO, 2010). The concept of vulnerability is closely associated with the lack of adaptation strategies, something that is common among the poorest.

Adaptation policies can initiate a virtuous circle that drives local employment: they prevent job losses by altering forms of production threatened by climate change, and they create jobs by preparing the country for climate change (particularly through infrastructure projects). Mitigation efforts aimed at reducing greenhouse gas (GHG) emissions change certain sectors of the economy, mainly those associated with fossil fuel energy production and those requiring a great deal of energy. The latter include the steel, iron and aluminium and road transport industries.

Changes in commercial standards also have an impact on employment, as growing consumer awareness can lead to shifts in consumption patterns and thus in labour markets. Another effect is the displacement of jobs because of carbon leakage, as the diversion of investments to territories where environmental standards are less stringent is termed. Climate change can also produce migratory flows from rural areas, where production capacity has been affected, to cities.

Environmental policy has clear effects on the production fabric, in some cases merging with green industrial policy. Indeed, some measures induce process innovations, with energy policy measures in particular seeking to transform the production structure to make it low-carbon, resource-efficient and more productive (Altenburg and Rodrik, 2017). 
From the above, it is possible to say that the transition to a greener economy will affect employment in four ways: (i) jobs will be created in new emerging green sectors, such as renewable energies, where demand for goods and services is expanding; (ii) certain jobs will be destroyed and not directly replaced, for example because certain methods are banned or discouraged; (iii) some jobs will be replaced as a result of industrial transformation; and (iv) most of today's jobs will be transformed and redefined in accordance with the new working methods and profiles required (UNEP and others, 2008).

The above considerations clearly illustrate that these processes provide opportunities, but also carry major risks for some sectors of employment. The concept of a just transition, which originated in the trade union movement and has now been adopted by the specialized agencies of the United Nations and governments, posits that a shift to a greener economy must consider all the actors involved. Social dialogue must be at the heart of the process, and governments, besides regulating GHG emissions, must play the fundamental role of promoting the kind of industrial and social policies that lead to the creation of productive and decent employment (ILO, 2015).

\section{Green employment}

In recent years, a number of policymakers, advocacy groups and researchers have held debates on the potential of climate policies to create green jobs. These are defined as jobs that, by meeting decent work standards, contribute to the preservation and restoration of the environment in traditional sectors, such as manufacturing and construction, or in new emerging sectors, such as renewable energy and energy efficiency (Jarvis, Varma and Ram, 2011). Diagram 1 illustrates this concept.

\section{Diagram 1}

Definition of green employment

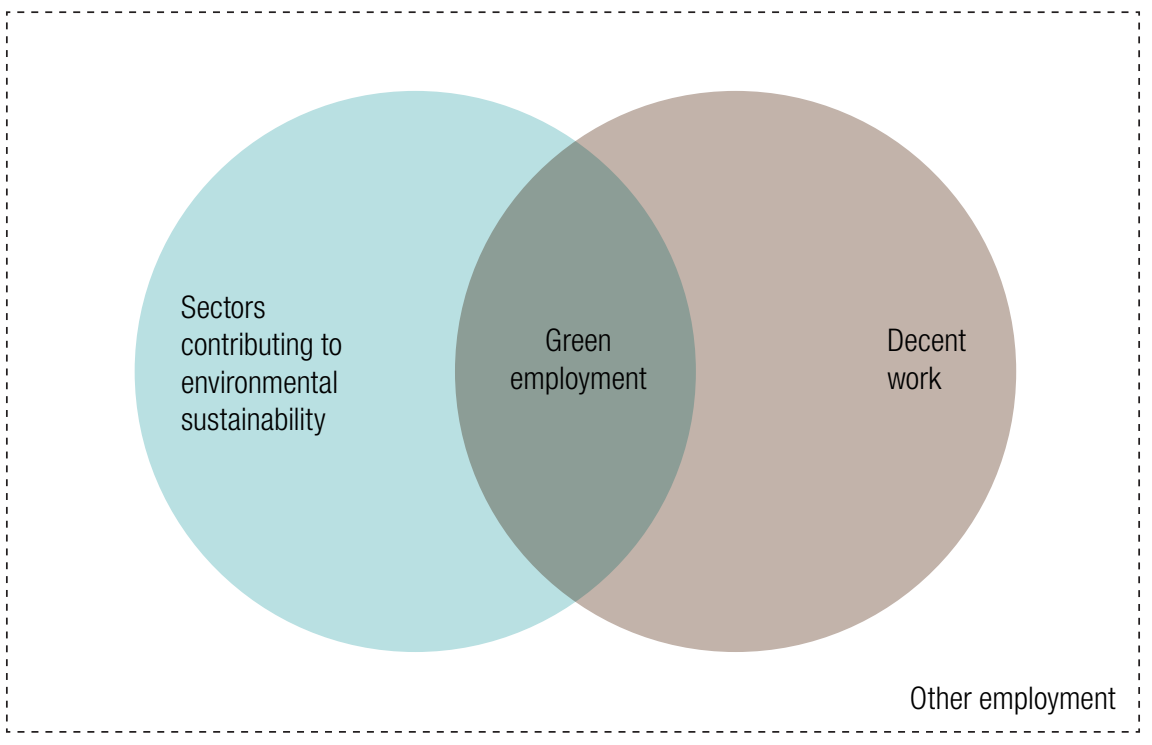

Source: A. Jarvis, A. Varma and J. Ram, Assessing Green Jobs Potential in Developing Countries: A Practitioner's Guide, Geneva, International Labour Organization (ILO), 2011.

"Decent work" is a concept developed by ILO that establishes the characteristics an employment relationship must have for work to be carried out "in conditions of freedom, equity, security and human dignity". For work to be decent, workers must have: (1) productive jobs with a fair wage, (2) good working conditions, (3) social protection, (4) labour rights, (5) equal opportunities between genders and (6) a say in decisions which will affect their lives (ILO, 2012). 
At the company level, green jobs may be in the production of goods or services that benefit the environment, such as water sanitation or reforestation. Again, firms may apply more environmentally friendly production processes without necessarily producing environmental goods or services, for example by reducing water consumption or improving their recycling systems. These are the jobs that reduce the environmental impact of companies and economic sectors, ultimately to sustainable levels (UNEP and others, 2008).

The universe of employment can be classified into four broad situations depending on whether the two attributes, decent work and environmental sustainability, are present.

Green employment, as already mentioned, meets the conditions of decent work and environmental sustainability (see diagram 2).

Environmental (non-green) employment is found in sectors that follow sustainable environmental practices but do not meet high enough labour standards for employment there to qualify as green. Examples of non-green environmental jobs are: informal and seasonal jobs and those carried out without the application of mandatory safety measures in some sectors of organic agriculture; the work of urban ragpickers and recyclers, when carried out under inappropriate conditions; and the work of informal workers who build small structures for better water management. This type of employment has immense potential to become green if productivity and working conditions are improved.

The remaining two situations are that of sectors where work is decent but environmental sustainability conditions are not met (lack of environmental policies) and that of sectors where both labour and environmental conditions are inadequate.

\section{Diagram 2}

The relationship between decent work and environmental sustainability

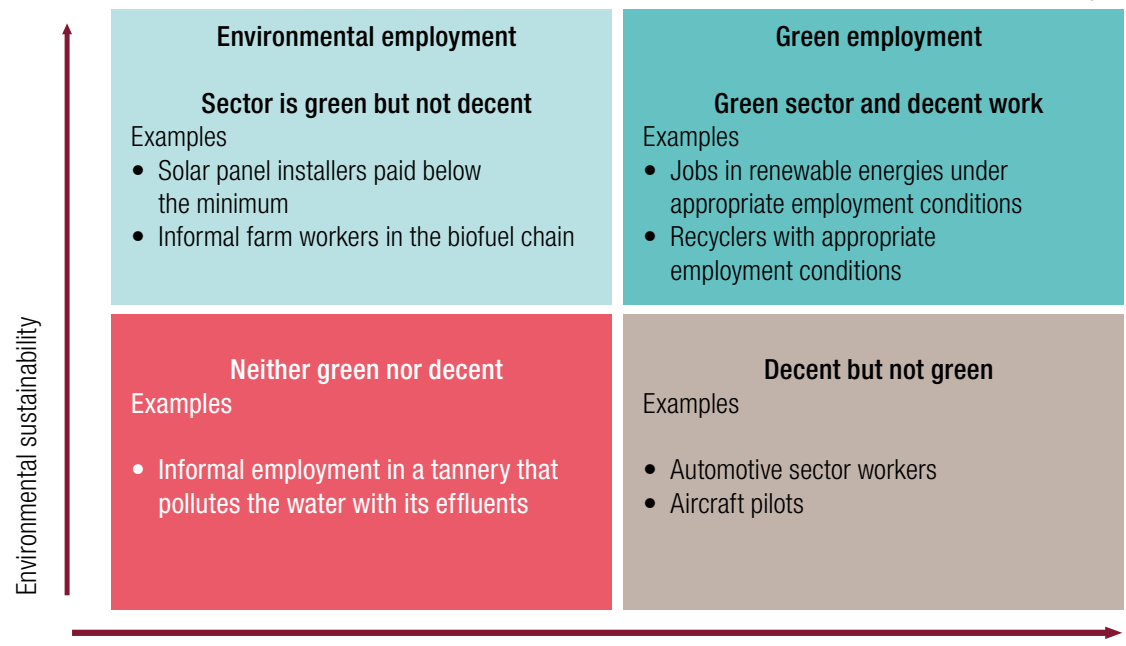

Decent work

Source: A. Jarvis, A. Varma and J. Ram, Assessing Green Jobs Potential in Developing Countries: A Practitioner's Guide, Geneva, International Labour Organization (ILO), 2011.

While the definition of green employment used by the International Labour Organization (ILO) and the United Nations Environment Programme (UNEP) is widely accepted, there is much debate about how to apply it in practice. Should green employment be estimated at the occupational, enterprise or sector level? Should it be restricted to industries that produce environmental goods and services, or should it be extended to other sectors of the production fabric that follow good environmental practices? Should direct employment or all employment generated in the value chains of green sectors be considered? These are the main points at issue. 
Some studies focus on occupations that have a clearly environmental objective (Keivani and others, 2010). However, these can be difficult to identify when they are traditional occupations performed in environmental activities (a metallurgy worker producing turbines for wind power). Other studies focus on production activities, restricting green employment to the environmental goods and services industry or, if they set out from the logic of greening the production fabric, including subsectors and companies that follow good environmental practices in traditional sectors (OECD/Eurostat, 1999; UNEP and others, 2008).

The focus on occupations offers great advantages, as it makes it possible to quantify the green jobs created in brown sectors, most of which (constrained by regulations or the markets) are making great efforts to improve their environmental performance. It thus seems to be the most appropriate criterion. However, it requires methodological efforts and sources of information on occupations that are not usually available.

Following the methodology proposed by the ILO Green Jobs Programme (Jarvis, Varma and Ram, 2011), the best match for the information sources available, green employment in Argentina was estimated by sector and company. This aspect is discussed in detail in the annex.

For this reason, the estimate for Argentina underestimates total green employment, as it does not include green occupations in brown sectors because of the impossibility of quantifying them from the information sources available.

\section{Green employment in Argentina: sectoral patterns and implications for employment quality}

With gross domestic product (GDP) of US\$ 546 billion (2016), Argentina is one of the largest economies in Latin America. It has abundant natural resources in energy and agriculture, is a leader in food production and has opportunities in some manufacturing subsectors and in innovative high-technology services.

In 2016, agriculture, livestock, forestry and fisheries accounted for 9\% of GDP and manufacturing for $21 \%$ (of which food and beverages accounted for 25\%). The population was 44 million, with an unemployment rate of $8.5 \%^{1}$ and an underemployment rate of $10 \%$. Informal employment (the proportion of unregistered wage earners) was 33.8\% (MTEySS, n/d a).

During the last 15 years, Argentina has gone through a process of economic growth driven by the primary and industrial sectors that has brought more people into the consumer market, mainly through formal employment. The institutional framework, being characterized by policies aimed at promoting the formalization of employment, social dialogue and the consolidation of the minimum, living and mobile wages and collective bargaining, helped ensure that this stage of economic growth would be accompanied by a process of social inclusion (Bertranou and Casanova, 2013). Indeed, registered wage employment increased by 63\% between 2000 and 2016, outstripping GDP growth in constant money terms (47\%), partly owing to the creation of new jobs and the formalization of unregistered jobs (see figure 1).

1 Third quarter of 2016. 
Figure 1

Gross domestic product (GDP), registered private sector wage employment and rate of unregistered employment, 2000-2016

(Index: 2000=100)

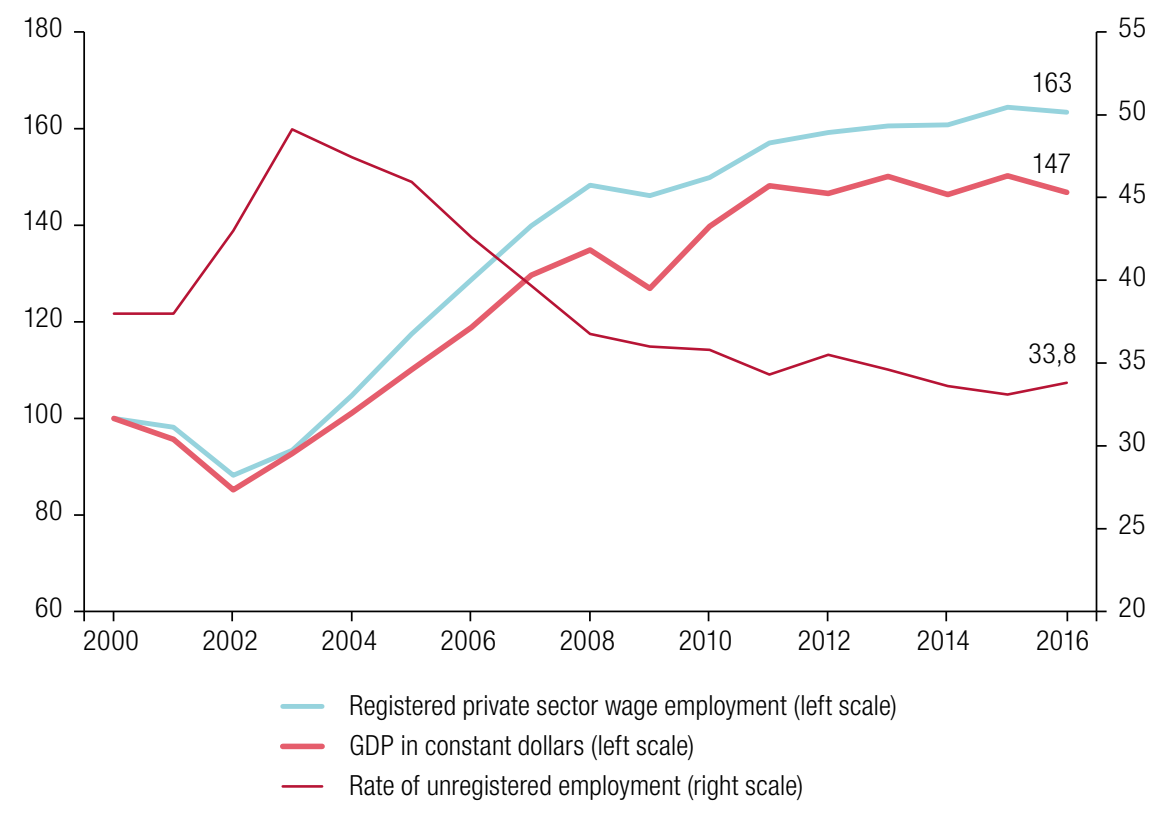

Source: Prepared by the authors, on the basis of the Permanent Household Survey of the National Institute of Statistics and Censuses (INDEC) and information from the Ministry of Labour, Employment and Social Security (MTEySS).

The strength and type of growth, driven by the expansion of agricultural and manufacturing activities, also had adverse environmental consequences. Perhaps the main problem was the deforestation that took place in the north of the country because of the advance of the agricultural frontier. In $2014,39.6 \%$ of greenhouse gas emissions came from energy production, followed by agriculture and livestock (26.9\%) and land use change and forestry (25.7\%). Although to a lesser extent, waste management (4.4\%) and industrial processes (3.3\%) also generated GHGs (SAyDS, 2015).

The loss of huge tracts of forest not only increased GHG emissions but also contributed to an increase in the frequency and intensity of the floods that affect people year after year (FAO, 2014; World Bank, 2016). Air pollution, waste management and water pollution have also become serious problems, particularly in urban centres (World Bank, 2016).

Since 2000, increasing efforts have been made to bring about a transition towards more environmentally sustainable growth paths, in the form of both public policies and private initiatives, often prompted by the requirements of export markets. Among these efforts, mention can be made of Law No. 25675, known as the General Environment Act (2002), which establishes the minimum prerequisites for achieving sustainable and appropriate management of the environment and encompasses different sectoral regimes. The result of these efforts has been lesser growth in GHG emissions (0.4\%) than in GDP (2.8\%), considering average annual rates for the period 2000-2014. This process has become more evident since 2009, when emissions fell (in a context of stagnant GDP), mainly owing to a slower rate of deforestation, falling livestock production and reduced emissions in the energy sector.

Efforts towards greater environmental sustainability have intensified since the change of government in 2016. A more active energy policy has been adopted, energy and fuel price subsidies have been cut and investment in renewable energy sources has been encouraged (RenovAr Programme). The implementation of flood prevention infrastructure works and the development of disaster monitoring 
systems (National Water Plan) are reducing the vulnerability of vast sectors of the population while creating green jobs. An effort is also being made to improve the environmental efficiency of the urban passenger transport system by expanding metro networks and urban infrastructure.

The transition to more socially and environmentally sustainable growth patterns is creating new activities and occupations in addition to the traditional ones. Many of these jobs are considered green, i.e. decent work in environmentally sustainable activities.

\section{The sectoral configuration of green employment}

Green jobs are found in practically all sectors of the Argentine economy. Some sectors are considered green by definition, such as sanitation and environmental protection, while in the rest of the production fabric green jobs are found in activities involving sustainable environmental practices, such as organic agriculture, energy-efficient industrial processes and research activities focused on environmental issues. ${ }^{2}$

It is estimated that there were between 486,000 and 650,000 green jobs in Argentina in 2015, representing $4 \%$ and $7 \%$ of registered wage earners, respectively. The difference between the two estimates depends on whether or not employment in public road passenger transport is considered green.

It should be noted that this estimate does not include environmental jobs in the informal sector of the economy, which are not considered green because of poor working conditions. The challenge for this type of employment is to improve productivity and guarantee access to labour rights.

Registered employees in "non-green" sectors and enterprises are shown in table 1. It was not possible to quantify green employment within these non-green enterprises from the sources available, so there is an underestimation bias.

Table 1

Argentina: sectoral composition of green employment, two estimation hypotheses, 2015

\begin{tabular}{|c|c|c|c|c|c|c|c|c|}
\hline & \multicolumn{2}{|c|}{$\begin{array}{c}\text { Registered } \\
\text { employees } 2015\end{array}$} & \multicolumn{3}{|c|}{$\begin{array}{l}\text { Green employment } \\
\text { (broad estimate }^{\mathrm{a}} \text { ) }\end{array}$} & \multicolumn{3}{|c|}{$\begin{array}{l}\text { Green employment } \\
\text { (narrow estimate }^{b} \text { ) }\end{array}$} \\
\hline & thousands & $\begin{array}{l}\text { percentage } \\
\text { of total }\end{array}$ & thousands & $\begin{array}{l}\text { percentage } \\
\text { of total }\end{array}$ & $\begin{array}{l}\text { percentage } \\
\text { of sector }\end{array}$ & thousands & $\begin{array}{l}\text { percentage } \\
\text { of total }\end{array}$ & $\begin{array}{l}\text { percentage } \\
\text { of sector }\end{array}$ \\
\hline $\begin{array}{l}\text { Agriculture, livestock, forestry } \\
\text { and fisheries }\end{array}$ & 366 & 4 & 58 & 9 & 16 & 58 & 12 & 16 \\
\hline $\begin{array}{l}\text { Agriculture, livestock, hunting } \\
\text { and allied services }\end{array}$ & 341 & 3 & 53 & 8 & 16 & 53 & 11 & 16 \\
\hline Forestry and timber extraction & 11 & 0 & 3 & 1 & 30 & 3 & 1 & 30 \\
\hline Fisheries and aquaculture & 15 & 0 & 2 & 0 & 11 & 2 & 0 & 11 \\
\hline Mining and quarrying & 97 & 1 & - & 0 & 0 & - & 0 & 0 \\
\hline Manufacturing & 1274 & 13 & 245 & 38 & 19 & 245 & 50 & 19 \\
\hline $\begin{array}{l}\text { Supply of electricity, gas, steam } \\
\text { and air conditioning }\end{array}$ & 71 & 1 & 11 & 2 & 15 & 11 & 2 & 15 \\
\hline $\begin{array}{l}\text { Supply of water, removal of waste } \\
\text { water, waste management }\end{array}$ & 59 & 1 & 48 & 7 & 83 & 48 & 10 & 83 \\
\hline Construction & 475 & 5 & 23 & 3 & 5 & 23 & 5 & 5 \\
\hline Transport and storage & 476 & 5 & 188 & 29 & 39 & 24 & 5 & 5 \\
\hline $\begin{array}{l}\text { Accommodation and } \\
\text { catering activities }\end{array}$ & 278 & 3 & 16 & 2 & 6 & 16 & 3 & 6 \\
\hline $\begin{array}{l}\text { Commerce and other personal and } \\
\text { business services not analysed }\end{array}$ & 6844 & 69 & 62 & 10 & 1 & 62 & 13 & 1 \\
\hline Total & 9939 & 100 & 650 & 100 & 7 & 486 & 100 & 5 \\
\hline
\end{tabular}

Source: Prepared by the authors, on the basis of International Labour Organization (ILO), Estimación del empleo verde en Argentina, Buenos Aires, 2017.

a Includes employment in road passenger transport.

b Excludes employment in road passenger transport.

2 The methodological aspects of estimating green employment in Argentina are detailed in the annex to this article. 
Taking the larger estimate $(650,000)$, most green jobs are in manufacturing (38\%), transport (29\%), the agriculture, livestock, forestry and fisheries sector (9\%) and water supply and waste management (7\%). Services and commerce linked to environmental protection account for $10 \%$. On the narrower estimation hypothesis $(486,000)$, the relative importance of sectors changes, with manufacturing $(50 \%)$ and agriculture, livestock, forestry and fisheries (12\%) even more to the fore (ILO, 2017).

To expedite the analysis, economic activities were then organized into four main groups or subsystems by the central issues common to them: (i) the exploitation of renewable resources, (ii) the production of energy and fuels, (iii) manufacturing and (iv) urban systems. The sectoral analysis presented below is based on Estimación del empleo verde en Argentina (ILO, 2017).

\section{(a) Exploitation of renewable resources}

The first subsystem that will be analysed is the exploitation of renewable resources, comprising agriculture, livestock, fisheries and forestry. In 2015, these activities represented 9\% of GDP, 7\% of formal employment and 23\% of Argentina's exports. If agro-industrial linkages are considered, the incidence of the primary sector in the national economy is even greater (Rodríguez, 2005). They also contribute greatly to the subsistence of poor rural populations, this being particularly the case with fisheries, forestry and small-scale agriculture. Employment conditions for workers in these sectors tend to be worse than the average for the economy: work is informal and not permanent (temporary and seasonal), and occupational hazards are greater than in other activities (Ohaco, 2012; CIFRA, 2011).

Alongside organic agriculture and livestock husbandry, technology-based conservation practices are among the good environmental practices of the agricultural sector, mainly in the form of precision agriculture, control of erosion by means of no till systems and control of soil and water pollution and the impact on biodiversity. Mention should also be made of waste management, with waste increasingly being used for energy production (Viglizzo and Frank, 2010; World Bank, 2016).

Meanwhile, the protection of forests and fishing resources requires the development of appropriate governance regimes and the institutions to implement them. Argentina has a highly sophisticated resource management model for both resources that creates a significant number of green public and private sector jobs in monitoring and oversight. In addition, producers oriented towards the external market use special seals of quality that certify good environmental practices.

Three strategies are used to identify producers following good environmental practices in these sectors. In the export sector, good agricultural, forestry and fisheries practices are identified by specific seals certifying them, mainly GlobalG.A.P. (Good Agricultural Practice), RTRS (Roundtable on Responsible Soy), FSC (Forest Stewardship Council) and MSC (Marine Stewardship Council).

This type of certification, which usually has a high cost for the producer, is not yet generally required in Argentina's domestic market. Producers oriented towards the domestic market who follow good agricultural practices join producer associations that are recognized for their strong environmental commitment, such as the Rural Change Programme, the Argentine No Till Farmers Association (AAPRESID) and the Argentine Association of Regional Consortiums for Agricultural Experimentation (AACREA).

The third strategy concerns highly regulated activities that require technicians and professionals with green jobs.

The livestock subsector provides some 58,000 green jobs, representing $16 \%$ of formal employees. While $15 \%$ of jobs associated with row crops (cereals, oilseeds, vegetables and industrial crops such as sugar cane and cotton) are green, the incidence of green employment is higher for permanent crops (mainly fruit), at $38 \%$. Just $7 \%$ of formal employment in the livestock subsector is green. 
The forestry sector employs 3,300 workers in green jobs (34\% of formal employment in the sector), engaged in production activities or technical or professional roles. In the fisheries sector, the number of green jobs is estimated at about 1,500, representing $21 \%$ of formal employment. There are a further 2,400 or so public sector employees in green jobs in the fishing sector, responsible for managing its regulatory framework.

\section{(b) Energy and fuel production}

Argentina's energy mix is currently dominated by fossil fuels: $53 \%$ of energy comes from natural gas and $33 \%$ from oil. The share of coal is very low, and renewable energies represent $10 \%$ of the primary supply (Ministry of Energy and Mining, 2016a). Although the production of renewable energy is still an incipient activity in Argentina, the high share of gas makes the energy sector relatively "clean" in comparison with other economies in the region. However, Argentina's energy sector presents problems of security in resource availability (connected to this dependence on gas and oil), as well as socioeconomic problems (some sections of the population do not have access to energy from the grid because of the country's size) and environmental problems (natural gas is the main generator of greenhouse gases) (SAyDS, 2015).

The development of renewable energy sources has been a priority area for policy in recent years. The country is seeking to diversify its energy supply and improve energy efficiency through various measures, such as reductions in consumer subsidies, incentives for investment in renewable sources (such as the cutting law requiring traditional fuels to contain a percentage of biofuels, the RenovAr programme and the PROBIOMASA programme) and programmes facilitating access to energy services for rural populations.

In 2015, there were an estimated 10,000 green jobs in small hydro (22\%), wind and solar power plants and in sectors linked to bioenergy production, such as biodiesel and bioethanol (46\%) and other forms of biomass (24\%).

\section{(c) Manufacturing}

Manufacturing is a diversified sector in Argentina and accounts for a large share of GDP (21\%). ${ }^{3}$ It includes agro-industries that supply the whole of the country's domestic demand and are a major component of exports. In addition, it comprises a variety of activities ranging from the production of textiles, metallurgical products, paper, the pharmaceutical sector, chemicals and petrochemicals, aluminium, steel and automobiles to the development of biotechnology applications, medical instruments and nuclear and space products.

A characteristic of Argentina's manufacturing sector is its great heterogeneity of production methods, with technology gaps, productivity gaps and agents of different sizes, among other things. It thus generates jobs with unequal working conditions in aspects such as pay, the degree of informality and job opportunities for women (Infante and Gerstenfeld, 2013). Manufacturing industry employed some 2.4 million people as of 2015 , of whom $79 \%$ were wage earners, with $69 \%$ of these in turn being registered.

This heterogeneity is also reflected in environmental performance: segments with low productivity that cannot afford adequate conditions of employment for their workers cannot afford appropriate environmental practices eith12er.

\footnotetext{
3 Value added in 2015, at 2004 prices.
} 
Both dimensions, the productivity gap and the type of sector, are relevant to an understanding of environmental performance. Manufacturing industry includes subsectors whose production processes negatively affect the environment, especially through GHG emissions and water pollution, as well as groups of companies striving to move towards more sustainable modes of production (SAyDS, 2015).

Predominant among good environmental practices in industry are actions aimed at using cleaner technologies and optimizing costs. Some of the most widely followed practices are the use of alternative fuels and recycled materials (paper and cardboard, aluminium, iron and steel, glass and plastics) and product life cycle analysis (SAyDS, 2015; Stumpo and Rivas, 2013). Demand from export markets plays a significant role, prompting the incorporation of clean technologies and new environmental management criteria by local producers. These requirements take the form of quality certifications with environmental content, such as organic product certifications, ISO 14000 and eco-labelling.

On the other hand, the environmental performance of industry does not seem to have been a central issue on the political agenda in recent decades. Indeed, among the good environmental practices of the sector, the treatment of effluents, emissions and waste seems to be less prevalent.

Argentina also produces numerous goods for environmental use, defined according to the criteria of the Organization for Economic Cooperation and Development (OECD) (Sugathan, 2013). Many of these goods form part of renewable energy value chains and are the subject of policies in a production development strategy with elements of a "green industrial policy" (INTI, 2013; SAyDS, 2015).

Green jobs in manufacturing are estimated at 245,000 (19\% of formal employees in the sector). This figure comprises both jobs linked to the production of goods for environmental use and jobs in companies that follow good environmental practices. A significant percentage are involved in the production of food and beverages in agro-industrial value chains that are environmentally certified during the primary stage (ILO, 2017).

\section{(d) Urban systems}

The fourth subsystem covers urban activities: waste management, water sanitation, transport and construction. Tourism is also included in this group because, although ecotourism is rural, most tourism activities in Argentina (hotels, restaurants and other services) are in urban areas.

Economic growth and access to consumption by increasingly large social groups are generating greater demand for urban systems. In Argentina, 92\% of the population is urban (INDEC, 2010). Consequently, the coverage and quality of these systems have a significant impact on citizens' quality of life and the competitiveness of the economy.

The country's long distances and low population density make transport a key service both for competitiveness and for people's quality of life. From an environmental perspective, the sector is very heterogeneous. Automotive transport (freight and passenger) is one of the activities generating most pollution (GHGs, noise, congestion, accidents), to the point where it is a constraint on the sustainability of cities, while rail and water transport are more sustainable alternatives.

Two estimates of green employment were carried out for this sector, reflecting the debate on the environmental performance of public passenger transport (although a major source of emissions, it represents a significant reduction in GHG emissions when compared to private motor transport). The first mode accounts for $13 \%$ of transport sector emissions and the second for $79 \%$ (SAyDS, 2015). Thus, on a broad perspective, there are some 187,000 green jobs in the transport sector, equivalent to $29 \%$ of registered employees. The proposed subsectors are rail, maritime and river, public passenger road transport and the underground system. On a narrow perspective, it is estimated that green jobs in the sector represent only $5 \%$ of registered employees. 
The coverage and quality of services in Argentina's sanitation and waste management systems need to increase: drinking water coverage extends to $83 \%$ of the population, $91 \%$ of households (urban and rural) have a regular waste collection service (only $64.7 \%$ of waste is properly disposed of) and $49 \%$ of the population has sewage coverage (INDEC, 2010). Inappropriate final disposal of waste has negative effects on the air and water. The sector emits 4.4\% of GHGs (SAyDS, 2015).

Construction emits large quantities of GHGs because its ecological footprint extends throughout the value chain. The country has not yet designed a strategy to promote mass construction of sustainable housing. In addition, there seems to be insufficient infrastructure to mitigate the effects of climate change.

The quality of employment in the activities making up urban systems is generally lower than the average for the economy. Construction, waste management, some transport subsectors and tourism have high rates of informality, poor working conditions and low skill requirements. In these activities, it is common to find contrasting situations: on the one hand, a formal subsector with pay and health coverage that is better than the average for the economy and, on the other, an informal subsector that operates in situations of extreme poverty.

Waste management and sanitation activities have created some 48,000 green jobs representing $83 \%$ of formal employment in the sector. In addition, the construction sector has created some 22,000 green jobs (equivalent to about $4 \%$ of registered employees in the sector) in five activities: the construction of green buildings, water infrastructure works, renewable energy infrastructure works, the installation of solar thermal energy equipment and professional services activities.

Tourism has the same environmental problems as other activities in the urban system: waste and water management and congestion seem to be the main negative environmental externalities associated with it. The main green activities in the sector are: the good environmental practices of some hotels and tourism agencies; activities carried out in protected areas, ecotourism and adventure tourism; the services of botanical gardens; the management of national parks; the maintenance of green spaces; and library and museum services. In addition, cultural and recreational activities such as theatre, entertainment and amusement park activities should be included when sustainably managed. Tourism provides some 16,000 green jobs (representing only 6\% of the sector's formal wage earners).

While not exclusively associated with any particular economic sector, there is a large set of business services that create green jobs $(62,000)$. This set is partly made up of regulatory and enforcement bodies (28,000 jobs), activities associated with technical testing and institutions investigating environmental issues $(9,000$ jobs), the trade in recycled materials $(5,000$ jobs) and trade unions and employers' organizations (4,000 jobs) (ILO, 2017).

\section{Green employment quality}

Under the methodology used to estimate it, as mentioned, green employment in Argentina is the percentage of formal wage employment, i.e. decent work, carried out in sectors that contribute to environmental sustainability. This means that it meets certain quality standards.

Because of its sectoral specialization, however (green employment is overrepresented in goods-producing sectors and among providers of some very specific services, such as sanitation and transport), green employment has characteristics that differentiate it from the jobs of other registered employees. To analyse these differences, some variables available from the Employment and Business Dynamics Observatory (OEDE) in 2015 were considered: remuneration, the qualifications required for the job and the percentages of men and women (see figure 2). ${ }^{4}$

\footnotetext{
4 The high level of sectoral disaggregation meant that it was not possible to carry out this analysis on the basis of the Permanent Household Survey.
} 
With respect to the first variable, it is observed that pay is $20 \%$ higher for green jobs than for other types of registered employment. Because of their sectoral specialization, green jobs are few and far between in lower-paid sectors such as commerce, construction and services such as education.

The second variable has to do with occupations. Most green jobs are held by workers with intermediate skills. A smaller percentage require unskilled or highly skilled workers. In fact, $58 \%$ of green jobs are done by craft and related trade workers, which is almost twice the percentage of workers with intermediate skills in total formal employment (30\%). At the same time, only $6 \%$ of green jobs require technical or higher qualifications, whereas this category constitutes approximately $13 \%$ of total registered wage employment.

With respect to the third variable, only about $13 \%$ of green employment is female (women represent $39 \%$ of total formal employment). Because the manufacturing, transport and agricultural sectors are so heavily represented, a large percentage of green jobs are held by men. However, public sector green employment tends to make up the difference, adding women. People aged under 25 account for $11 \%$ of green employment (young people account for $13 \%$ of total registered wage employment) and play a very important role in the agricultural, construction and tourism sectors.

Figure 2

Argentina: characteristics of green employment and total registered wage employment, 2015 (Percentages)

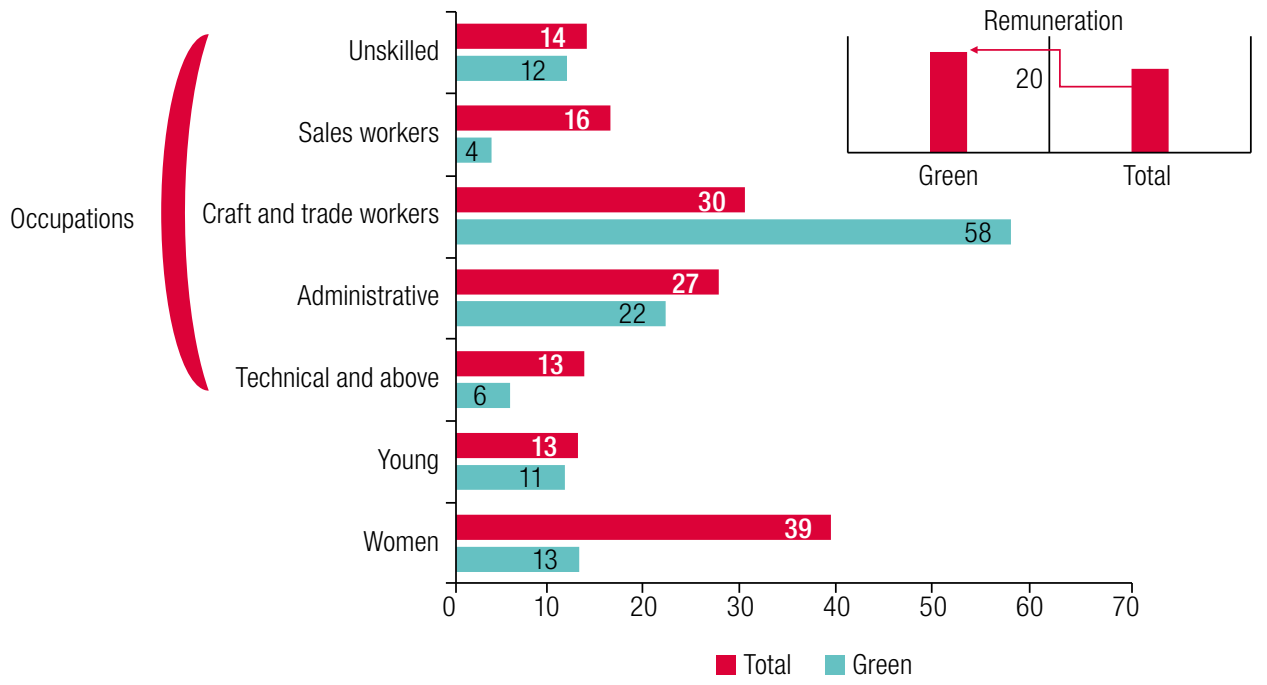

Source: Prepared by the authors, on the basis of Ministry of Labour, Employment and Social Security (MTEySS).

Opportunities to create better-quality green jobs are found in activities that incorporate more knowledge and technological complexity. Thus, the best-paid green jobs are associated with the production of renewable energy, manufacturing industry (particularly the most technology-intensive branches) and professional services. These activities also employ more women and a higher percentage of workers with technical or higher qualifications (see table 2).

Remuneration for green jobs in the food and beverage production sector is also above average (although highly competitive in Argentina, this sector is included in the low technology intensity category by the Organization for Economic Cooperation and Development (OECD)). 
Table 2

Argentina: characteristics of green employment by subsystem

\begin{tabular}{|c|c|c|c|c|c|}
\hline & Distribution of & & Percen & es of work & \\
\hline & $\begin{array}{l}\text { employment } \\
\text { (percentages) }\end{array}$ & Remuneration & $\begin{array}{l}\text { Technical or higher } \\
\text { qualifications }\end{array}$ & Female & Young \\
\hline (i) Exploitation of renewable resources & & 9206 & 2 & 16 & 22 \\
\hline (ii) Energy and fuels & & 39907 & 16 & 15 & 5 \\
\hline (iii) Manufacturing industry ${ }^{a}$ & 100 & 22529 & 7 & 13 & 11 \\
\hline Low technology intensity & 32 & 24156 & 7 & 16 & 12 \\
\hline Medium-low technology intensity & 14 & 15088 & 7 & 8 & 13 \\
\hline Medium-high technology intensity & 50 & 23335 & 6 & 11 & 10 \\
\hline High technology intensity & 4 & 25152 & 24 & 26 & 10 \\
\hline (iv) Urban systems & 100 & 20124 & 4 & 10 & 9 \\
\hline Professional services & 11 & 22376 & 21 & 33 & 9 \\
\hline Other & 99 & 19947 & 4 & 10 & 9 \\
\hline Total & & 20255 & 6 & 13 & 11 \\
\hline
\end{tabular}

Source: Prepared by the authors, on the basis of Ministry of Labour, Employment and Social Security (MTEySS).

a The Organization for Economic Cooperation and Development (OECD) classification of technology intensity is employed.

The data indicate that green jobs may have better conditions of employment than other formal sector jobs and that this is particularly the case when firms are in technology-intensive and knowledge-intensive sectors. Higher productivity levels make it possible to afford better pay, more job promotion opportunities (the percentage of highly skilled workers is higher) and more women in employment.

\section{Public policies and green employment: some aspects of the Argentine experience}

The creation of green jobs largely hinges on the ability to formulate coordinated and effective public policies aimed at improving the environmental sustainability of some sectors and the quality of employment in others. Such policies should also aim at anticipating and mitigating possible unintended effects on employment.

This requires a high degree of integration, consistency and coordination between institutions and the initiatives undertaken (Lerda, Acquatella and Gómez, 2005), attributes that are often not present in the Argentine context (Rezk, 2005). Environmental issues have moved up the Argentine political agenda in the last 25 years, thanks to which there have been major advances in the country's regulatory framework. However, the transition to a green and inclusive economy is not yet part of national employment policy, and the institutional framework continues to present shortcomings in terms of coordination.

Some aspects of environmental policy in Argentina are presented below, with particular emphasis on initiatives that contribute to the creation of high-quality jobs and the transition to a green economy. 


\section{The importance of environmental issues on the political agenda and the development of the regulatory framework}

The constitutional reform of 1994 shaped the current structure of environmental responsibilities. The national authorities were given the power to legislate on minimum standards, while the right to delineate the legislative development of the resulting statutes by regulating and supplementing them was reserved for the provinces. Although consistent with the federal nature of the country and its heterogeneous territorial context, the legislative overlap in the federal regulatory framework can create ambiguous situations and slow down its application (Ábalos, 2011). Particularly in interdisciplinary and cross-cutting areas such as the environment, vertical and horizontal coordination problems are common (Rezk, 2005). An emblematic example is Law No. 26418/2010 on minimum standards for the protection of glaciers. Provincial governments, concerned about the restrictions the law places on economic activities around glaciers, introduced provincial legislation in an assertion of regulatory authority on the issue.

Although environmental issues have become more prominent in Argentina, there is still a tendency not to prioritize them when designing policy. This is reflected in the national budget allocated to green activities in 2016: for every peso allocated to the environment, 16 pesos were invested in activities with negative environmental impacts (brown activities) (Di Paola, 2017).

Environmental initiatives are often pursued in response to complex environmental situations and not as a result of strategic and preventive planning (CEMA, 2015). This is the case with the laws on watershed management, which arose in response to flooding and the "battle of Gualeguaychú" against the construction of paper mills. Furthermore, the importance of responsible consumption is only beginning to be recognized locally, and when products are environmentally certified it is often to meet the demands of foreign trade.

The low priority given to environmental issues in policy design is also seen at the stages of implementing and monitoring measures. An example is the partial application in the province of Buenos Aires of the law on thermal insulation of buildings, ${ }^{5}$ owing to the lack of an effective oversight and monitoring system (Vagge and Czajkowski, 2012). The passivity of consumers, who show no interest whatsoever in demanding compliance with standards, is worth noting, as it reveals how little of a factor responsible consumption is in the country.

\section{VII.Coordination between production, labour and environmental policies: energy}

Perhaps because of the low priority given to environmental issues on the public agenda, environmental, production and labour policies have not been properly coordinated. Production development policies are the most established, and these do not generally contain a strong commitment to environmental issues. In recent years, however, good practices have been observed in all three policy agendas, particularly the "green production development policy" agendas.

The most important example belongs to the area of renewable energies. With Law No. $27191^{6}$ of 2015, the Government of Argentina evinced a determination to diversify the country's energy supply

\footnotetext{
5 Law No. 13059, enacted in 2010.

6 National Incentive Regime for the Use of Renewable Sources of Energy for Electricity Production. The aim is for $20 \%$ of the country's electricity consumption to be met from the various types of renewable energy by 2025 .
} 
by making new investments in renewable energies with a view to moving the country away from dependence on fossil fuels and promoting job creation. The expansion of renewable energies generates direct employment in rural areas that, although rich in renewable natural resources, are characterized by a lack of job opportunities for their inhabitants. The expansion of these technologies in rural areas brings benefits to the whole community: the construction of new infrastructures or the improvement of existing ones gives rise to new SMEs and generates clusters of knowledge for local development. A number of programmes are being created within this framework, notably the RenovAr plan, which is expected to reduce annual carbon emissions by 2 million tonnes, saving US\$ 300 million in fuel and generating 5,000 to 8,000 direct and indirect jobs (Ministry of Energy and Mining, 2016b).

Argentina is also developing energy policies with specific social goals. The PERMER programme, for example, seeks to install wind or solar power generation systems in rural and remote areas that do not have adequate energy, hot water, heating or cooking facilities. The project is a valuable public policy instrument that integrates economic, social and environmental objectives. Another example is the Law for the Promotion and Development of Solar Energy in Jujuy, ${ }^{7}$ which not only establishes a sustainable energy policy but emphasizes that investment helps to reduce poverty and mitigate the effects of climate change. The law gives special priority to ventures that contribute qualitatively and quantitatively to the development of Jujuy's workforce and strengthen the development chain of local suppliers. ${ }^{8}$

\section{The preparation of prospective studies and formalization of the green economy concept}

The strategic planning and direction of environmental policies that are integrated with production development and the creation of decent work and are capable of fostering sustainable development requires effective diagnostic studies to be carried out. The prospective studies conducted by the Ministry of Science and Technology, which have been extensively debated at the national and local levels, are a case in point.

Two emblematic cases are: (1) the Pampa Azul initiative, which has the twofold objective of exploring marine frontiers and their potential for marine energy generation and effectively monitoring fishing activities, and (2) the development of the bioeconomy in Argentina. ${ }^{9}$ The latter initiative has the potential to encompass numerous interconnected value chains: all agricultural, forestry, fisheries and aquaculture activities, the food and beverage industries and the pulp and paper industries, as well as certain segments of the chemical, pharmaceutical, cosmetics, textile and energy industries (Trigo, 2005). Both studies are contributing considerably to the design of industrial and development policies that are taking on a bioeconomic perspective and boosting employment in high-productivity sectors.

Lastly, although at the national level there are no public sector initiatives that specifically bear on the concepts of the green economy or green employment (Alzari, 2017), some local authorities, such as those of the Autonomous City of Buenos Aires and Santa Fe, do make explicit reference to these concepts. In Buenos Aires, the green economy is an active and specific area of work, and the city authorities recognize and use the concept of green employment formulated by ILO. Law No. 1854/05, for example, not only prescribes a set of measures aimed at efficient and sustainable waste management, but also formalizes urban ragpickers and includes them in a single mandatory register. So far, 12 cooperatives

\footnotetext{
7 Law No. 5904, enacted in 2016.

8 Art. 18, Law No. 5904 (Province of Jujuy), San Salvador de Jujuy, 25 January 2016.

9 See [online] http://www.mincyt.gob.ar/accion/pampa-azul-9926; http://www.bioeconomia.mincyt.gob.ar.
} 
and more than 5,300 ragpickers have been formalized in Buenos Aires. ${ }^{10}$ Integrating these concepts into the national regulatory framework could be a valuable tool for inclusive and sustainable growth.

\section{Final reflections}

The transition to a green economy is a process Argentina has no choice but to embark on. Adaptation efforts to reduce the country's vulnerability to the effects of climate change, the commitments made to mitigate these effects and society's growing awareness of the importance of following inclusive development paths that respect the environment are factors driving this process.

The challenge of moving towards a green economy and at the same time generating decent work for people requires strong synergy between environmental, economic and industrial policies, as well as labour policies. The goal of a sustainable economy requires a shift in the production model towards smarter and more innovative, efficient and competitive configurations.

The transition presents opportunities for the creation of new high-quality jobs that the country can capitalize on if it implements the right policies, but also challenges for some sectors that will have to be transformed, leading to job losses. Labour and social protection policies must provide support in this process.

Argentina's experience shows that green jobs are the product of society's efforts towards sustainable development. In 2015, $7 \%$ of registered wage-paying jobs in the country were green. Although found in all sectors of the economy, they predominated in goods-producing activities and in specific urban services, such as sanitation and transport. Regulations, public policies and foreign trade requirements seem to be the main factors driving the creation of this type of employment, while responsible consumption does not yet play the key role it does elsewhere. In these jobs, on average, workers have better employment conditions than other registered employees (although there is less female employment), and these conditions are better in subsectors that incorporate a broader array of knowledge.

These results show that the transition to a green economy offers opportunities for the creation of high-quality jobs and that developing managerial, institutional and productive capabilities is crucial if they are to be capitalized on.

For the transition to a green economy to be fair, then, public policies must consider the employment dimension, and this can set in motion a virtuous circle leading to a more environmentally friendly, productive and socially inclusive economy.

\footnotetext{
10 See [online] http://www.buenosaires.gob.ar/ciudadverde/separacion/separacion-en-origen/cooperativas-de-recuperadores-urbanos.
} 


\section{Bibliography}

Ábalos, M. G. (2011), "Ambiente y minería: distribución de competencias en el federalismo argentino", La Ley, Suplemento Constitucional, Buenos Aires, Thomson.

Altenburg, T. and C. Assmann (eds.), (2017), Green Industrial Policy. Concept, Policies, Country Experiences, Geneva/Bonn, UN Environment/German Development Institute.

Altenburg, T. and D. Rodrik (2017), "Green Industrial Policy: Accelerating Structural Change towards Wealthy Green Economies", Green Industrial Policy. Concept, Policies, Country Experiences, T. Altenburg and C. Assmann (eds.), Geneva/Bonn, UN Environment/German Development Institute.

Alzari, M. J. (2017), Estado de arte en materia de empleo y economía verde en Argentina: las políticas, regulaciones e iniciativas privadas (sociedad civil, empresas) a nivel nacional y provincial, Buenos Aires, unpublished.

Amarante, V. and R. Arim (2015), Desigualdad e informalidad: un análisis de cinco experiencias latinoamericanas, ECLAC Books, No. 133 (LC/G.2637-P), Santiago, Economic Commission for Latin America and the Caribbean (ECLAC).

Bertranou, F. and L. Casanova (2013), Informalidad laboral en Argentina: segmentos críticos y políticas para la formalización, Buenos Aires, International Labour Organization (ILO).

CEMA (Business Chamber for the Environment) (2015), Propuestas de politicas ambientales para la Argentina que viene, Buenos Aires.

CIFRA (Research and Training Centre of the Argentine Republic) (2011), "Rentabilidad, empleo y condiciones de trabajo en el sector agropecuario", Documento de Trabajo, No. 8, Buenos Aires.

Di Paola, M. (2017), "El presupuesto climático rumbo al 2017: todo sigue igual", Informe ambiental anual 2017, Buenos Aires, Environment and Natural Resources Foundation (FARN).

Domínguez, M. and others (2016), Escenarios sobre calidad e inocuidad en el sector productor de materias primas y alimentos elaborados en Argentina (2030), Buenos Aires, Ministry of Science, Technology and Productive Innovation (MINCyT).

ECLAC (Economic Commission for Latin America and the Caribbean) (2016), Horizons 2030: Equality at the Centre of Sustainable Development (LC/G.2660/Rev.1), Santiago.

European Commission and others (2016), System of National Accounts 2008 (ST/ESA/STAT/SER.F/2/Rev.5), New York [online] https://unstats.un.org/unsd/nationalaccount/docs/sna2008.pdf.

Eurostat (Statistical Office of the European Communities) (2009), The Environmental Goods and Services Sector. A Data Collection Handbook, Luxembourg, European Commission.

FAO (Food and Agriculture Organization of the United Nations) (2014), Evaluación de los recursos forestales mundiales 2015. Informe Nacional Argentina, Rome [online] http://www.fao.org/3/a-az153s.pdf.

ILO (International Labour Organization) (2017), Estimación del empleo verde en Argentina, Buenos Aires, unpublished. (2016), Empleos verdes para un desarrollo sostenible. El caso uruguayo, Montevideo.

(2015), Guidelines for a just transition towards environmentally sustainable economies and societies for all, Geneva.

(2013a), Evaluation of the Potential of Green Jobs in Mexico, Geneva.

(2013b), Sustainable development, decent work and green jobs, Geneva.

(2012), Working towards Sustainable Development: Opportunities for decent work and social inclusion in a green economy, Geneva.

(2011), Social Protection Floor for a Fair and Inclusive Globalization. Report of the Advisory Group chaired by Michelle Bachelet, Geneva.

(2010), "Climate Change and Labour: The Need for a Just Transition", International Journal of Labour Research, vol. 2. No. 2, Geneva.

(2009), Empregos verdes no Brasil: quantos são, onde estão e como evoluirão nos próximos anos, Brasilia.

INDEC (National Institute of Statistics and Censuses) (2010), Censo nacional de población, hogares y viviendas 2010. Censo del Bicentenario. Resultados definitivos, Series B, vol. 1, No. 2, Buenos Aires [online] https:// www.indec.gob.ar/ftp/cuadros/poblacion/censo2010_tomo1.pdf.

Infante, R. and P. Gerstenfeld (eds.) (2013), Hacia un desarrollo inclusivo: el caso de la Argentina (LC/L.3569), Santiago, Economic Commission for Latin America and the Caribbean (ECLAC)/International Labour Organization (ILO).

INTI (National Institute of Industrial Technology) (2013), “Generadores eólicos: el tamaño sí importa”, Buenos Aires. IPCC (Intergovernmental Panel on Climate Change) (2015), Climate Change 2014. Synthesis report, Geneva, World Meteorological Organization (WMO)/United Nations Environment Programme (UNEP). 
Jarvis, A., A. Varma and J. Ram (2011), Assessing Green Jobs Potential in Developing Countries: A Practitioner's Guide, Geneva, International Labour Organization (ILO).

Keivani, R. and others (2010), "Green Jobs Creation through Sustainable Refurbishment in the Developing Countries", Working Paper, No. WP275, Geneva, International Labour Organization (ILO).

Lerda, J., J. Acquatella and J. J. Gómez (2005), "Coordinación de políticas públicas: desafíos y oportunidades para una agenda fiscal-ambiental", Política fiscal y medio ambiente: bases para una agenda común, ECLAC Books, No. 85 (LC/G.2274-P), J. Acquatella and A. Bárcena (eds.), Santiago, Economic Commission for Latin America and the Caribbean (ECLAC).

MAyDS (Ministry of Environment and Sustainable Development) (2017a), Informe del estado del ambiente 2016, Buenos Aires.

(2017b), Inventario nacional de gases de efecto invernadero, Buenos Aires.

Ministry of Energy and Mining (2016a), "Balance Energético Nacional 2015", Buenos Aires.

(2016b), RenovAr, Plan de Energías Renovables, Argentina 2016-2025, Ronda 1: llamado a convocatoria abierta nacional e internacional, July.

MTEySS (Ministry of Labour, Employment and Social Security) (n/da), "Boletín de estadísticas laborales (BEL)", Buenos Aires.

(n/db), "Observatorio de empleo y dinámica empresarial", Buenos Aires.

OECD (Organization for Economic Cooperation and Development) (2017), Employment Implications of Green Growth: Linking Jobs, Growth, and Green Policies, Paris, OECD Publishing.

OECD/Eurostat (Organization for Economic Cooperation and Development/Statistical Office of the European Communities) (1999), The Environmental Goods and Services Industry: Manual for Data Collection and Analysis, Paris, OECD Publishing.

Ohaco, M. (2012), "Precariedad y no registro en los trabajadores asalariados rurales de la Argentina", Trabajo, ocupación y empleo, Buenos Aires, Ministry of Labour, Employment and Social Security.

Rezk, E. (2005), "Fallas de coordinación: desafíos de política para el federalismo fiscal-ambiental argentino", Environment and Development series, No. 115 (LC/L.2428-P), Santiago, Economic Commission for Latin America and the Caribbean (ECLAC).

Rodríguez, J. (2005), "Los complejos agroalimentarios y el empleo: una controversia teórica y empírica", Working Paper, No. 3, Buenos Aires, Argentine Development Research Centre (CENDA).

Stumpo, G. and D. Rivas (comps.) (2013), La industria argentina frente a los nuevos desafíos y oportunidades del siglo XXI (LC/L.3637), Santiago, Economic Commission for Latin America and the Caribbean (ECLAC).

SAyDS (Secretariat of Environment and Sustainable Development) (2015), Primer reporte de actualización bienal de la República Argentina ante la Convención Marco de las Naciones Unidas sobre el cambio climático, Buenos Aires.

Stern, N. (2006), The Economics of Climate Change: The Stern Review, Cambridge, Cambridge University Press.

Sugathan, M. (2013), Lists of Environmental Goods: An Overview, Geneva, International Centre for Trade and Sustainable Development (ICTSD).

Sustainlabor (International Labour Foundation for Sustainable Development) (2009), Draft Report: Green Jobs and Women Workers, Employment, Equity, Equality [online] http://apgreenjobs.ilo.org/resources/ green-jobs-and-women-workers-employment-equity-equality.

Trigo, E. (2005), Reflexiones sobre las oportunidades que ofrece la biotecnología agropecuaria a los países de América Latina y el Caribe y las opciones de políticas a impulsar para su desarrollo, Buenos Aires [online] http://www.pymesonline.com/uploads/tx_icticontent/R01938_biotecnologia.pdf.

UNEP (United Nations Environment Programme) and others (2008), Green Jobs: Towards Decent Work in a Sustainable, Low-Carbon World, Nairobi, United Nations Environment Programme (UNEP).

Vagge, C. and J. Czajkowski (2012), "Impacto de la aplicación de la Ley 13.059 de Eficiencia Energética en relación a la nueva Ordenanza de Usos del Suelo de la ciudad de La Plata y la Norma IRAM 11900 de Etiquetado de Edificios", Ambiente Construído, vol. 12, No. 2, Porto Alegre, National Built Environment Technology Association.

Viglizzo, E. and F. Frank (2010), "Erosión del suelo y contaminación del ambiente", Expansión de la frontera agropecuaria en Argentina y su impacto ecológico-ambiental, E. Viglizzo and E. Jobbágy (eds.), Buenos Aires, National Institute for Agricultural Technology (INTA) [online] http://catalog.ipbes.net/system/assessment/3/ references/files/16/original/50._Argentina_Expansi\%C3\%B3n_Frontera_Agropecuaria_2010.pdf?1346944833.

Voices Resarch and Consultancy (2016), Radar de sustentabilidad 2015, Buenos Aires.

Worl Bank (2016), "Country environmental analysis: Argentina", Series of Technical Reports of the World Bank in Argentina, Paraguay and Uruguay, No. 9, Washington, D.C. 


\section{Annex A1}

\section{Methodology for estimating green employment in Argentina}

This annex summarizes the main aspects of the methodological chapter of the study Estimación del empleo verde en Argentina (ILO, 2017), which provides the framework for this article.

\section{Definition of green employment in Argentina}

Green employment is that generated in a green economy, simultaneously encompassing the economic, social and environmental dimensions. To be included in this category, jobs must be in environmentally sustainable sectors and meet the standards for decent work, a concept defined by ILO that establishes the characteristics an employment relationship must have for work to be carried out "in conditions of freedom, equity, security and human dignity" (ILO, 2012).

\section{Estimation strategy}

The methodology used to estimate green employment in Argentina was taken from the manual Assessing Green Jobs Potential in Developing Countries: A Practitioner's Guide (Jarvis, Varma and Ram, 2011). Using a mixed approach, various techniques were employed, such as the collection of statistical and qualitative information from key informant interviews and the analysis of quantitative data from different sources.

The process was implemented in three major stages. The first stage was to analyse the links between the production, environmental and labour dimensions throughout the economy by means of an exhaustive analysis of the literature and environmental and labour regulations, and of the key informant interviews. Second, the sectors, subsectors and groups of companies following good environmental practices were estimated and labour conditions were analysed. The third stage was to validate the results obtained in workshops and meetings with sectoral representatives, following the tripartite logic of ILO.

\section{Criteria for identifying green sectors}

In the study on Argentina, two key criteria were followed to identify green sectors: (i) activities that produce environmental goods and services and (ii) companies that follow good environmental practices in different sectors of the production structure.

Activities producing environmental goods and services were identified from international experience (OECD/Eurostat, 1999; OECD, 2017; Eurostat, 2009; UNEP and others, 2008). These activities were evaluated locally before being deemed green in the case of Argentina.

Some criteria for determining whether activities are green fall outside the logic of production sectors and show how much heterogeneity there can be within a given branch of activity or region at any particular time, with some producers making efforts to introduce more environmentally sustainable methods and others not. Diagram A1.1 summarizes these criteria. 
Diagram A1.1

Criteria for identifying green sectors

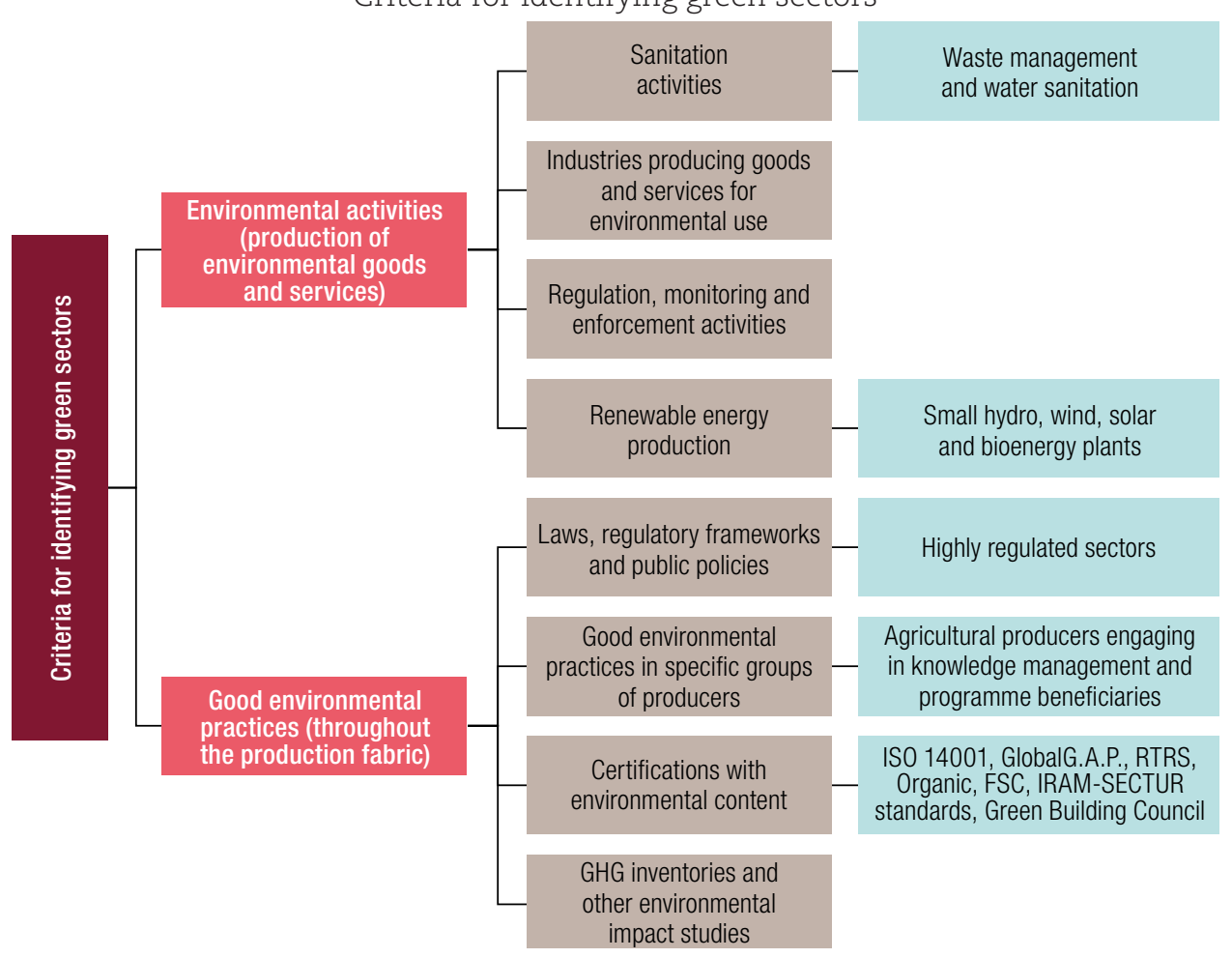

Source: Prepared by the authors.

\section{Decent work}

To identify decent work in the study on Argentina, wage employment contributing to the social security system was taken as a proxy variable. The union membership rate in Argentina is high. The country has a minimum, living and mobile wage policy and active collective bargaining to update the basics of the agreements. However, the benefits largely accrue to registered wage earners. Female employment in the branch was also analysed as a way of considering the extent of decent work associated with the creation of job opportunities for different worker profiles.

\section{Unit of analysis}

All employment that meets decent work standards and is carried out in environmentally sustainable companies is considered green. The study is not able to disaggregate "green occupations".

\section{Information sources}

The main source used to estimate employment was the Employment and Business Dynamics Observatory (OEDE). Employment conditions were evaluated mainly on the basis of the Permanent Household Survey conducted by the National Institute of Statistics and Censuses (INDEC), the Survey of Workers conducted by the Ministry of Labour and the system of accident indicators operated by the Superintendency of Occupational Risks (SRT). 